\title{
ANALYSIS AND OPTIMAL DESIGN THE EFFECT OF DESIGN VARIABLES ON MAGANIFICATION RATIO OF A MAGANIFICATION MACHANISM EMPLOYING FLEXIBLE HINGE
}

\author{
VAN-NANG DO \\ Faculty of Automotive Engineering Technology, Industrial University of Ho Chi Minh City \\ dovannang@iuh.edu.vn
}

\begin{abstract}
In order to high work performant for compliant mechanism about motion scope, work long term and high frequency. Therefore, in this investigation displacement, maximum principal stress and the first modal shape frequency were analyzed by Finite element analysis (FEA) for a magnification mechanism to find out effects of design variables on magnification ratio of this mechanism. The FEA outcomes indicated that design variables have significantly affected on magnification ratio, maximum principal stress and the first modal shape frequency of a magnification mechanism. The magnification ratio obtained 42.83 times thereby maximum principal stress is equal to $132.79 \mathrm{MPa}$ and the first modal shape frequency is equal to $377.44 \mathrm{~Hz}$, respectively. The forecast results by the Taguchi method achieve a displacement of $0.4392 \mathrm{~mm}$, and according to this method the optimal structure has a displacement of $0.4451 \mathrm{~mm}$ with the dimensions of the following variables: variable $A$ is $0 \mathrm{~mm}$, variable $B$ is $23 \mathrm{~mm}$ and $C$ is $60 \mathrm{~mm}$, the parameters combine at the levels A1B2C1. This structure amplified 44.51 times, this result is a good agreement compared with the forecast results, the error compared to the forecast is $1.33 \%$.the forecast results, the error compared to the forecast is $1.33 \%$.
\end{abstract}

Keywords. Magnification mechanism, flexure hinge, Finite element analysis, Magnification ratio.

\section{PHÂN TÍCH CHUYỂN VỊ VÀ ÚNG SUÂTT CỦA CƠ CẤU KHUẾCH ĐẠI SỬ DỤNG PHƯƠNG PHÁP PHẦ TỬ HŨ̂U HẠN}

TÓM TÁ̆T.Để nâng cao hiệu suất làm việc cho cơ cấu đàn hồi về phạm vi làm viêc, làm việc lâu dài và tần số cao. Vì vậy, trong nghiên cứu này chuyển vị, ứng suất chính cực đại và dạng tần số riêng đầu tiên đã được phân tích bằng phương pháp phân tích phần tử hữu hạn cho cơ cấu khuếch đại để tìm ra ảnh hưởng của các biến thiết kế đến độ khuếch đại của cơ cấu này. Kết quả phân tích phần tử hữu hạn đã chỉ ra rằng các biến thiết kế có ảnh hưởng quan trọng đến độ khuếch đại, ứng suất chính cực đại và dạng tần số riêng đầu tiên. Độ khuếch đại đạt 42.83 lần trong khi ứng suất chính cực đại bằng $132.79 \mathrm{MPa}$ và tần số riêng đầu tiên bằng $377.44 \mathrm{~Hz}$. Kết quả dự báo theo phương pháp Taguchi đạt được độ chuyển vị là $0.4392 \mathrm{~mm}$, và theo phương pháp này cơ cấu tối ưu có độ chuyển vị là $0.4451 \mathrm{~mm}$ với các kích thước của các biến như sau: biến $\mathrm{A}$ là $0 \mathrm{~mm}$, biến $\mathrm{B}$ là $23 \mathrm{~mm}$ và biến $\mathrm{C}$ là $60 \mathrm{~mm}$, các thông số kết hợp tại các mức $\mathrm{A} 1 \mathrm{~B} 2 \mathrm{C} 1$. Cơ cấu này khuếch đại lên 44.51 lần, kết quả này là đồng ý tốt so với kết quả dự báo, sai số so với dự báo là $1.33 \%$.

Từ khóa. Cơ cấu khuếch đại, Khớp bản lề đàn hồi, Phân tích phần tử hữu hạn, độ khuếch đại.

\section{Introduction}

The study of development of effective precision positioning mechanisms has challenges. Because the essential need for state-of-the art technologies in several industries, such as semiconductor manufacturing, where ultra-precise machining and micro-electro-mechanical-systems (MEMS) are mandatory. For example, a $0.15-1(130 \mathrm{~nm})$ process on $300 \mathrm{~mm}$ silicon wafer has recently been developed and a $65 \mathrm{~nm}$ process will be realized soon. A new actuating mechanisms and control strategies are essential to overtake the current limitations and obtain precision position in the nanometer range. One method to solving this kind of problems is to design new flexure hinges powered by piezoelectric actuators.

In recent a few decades, many kind of flexible hinges applied for many compliant mechanisms to limit the use of classical joints. The circular flexible hinge was utilized for 3-RRR compliant mechanisms, 3-DOF mechanism and 3-DOF parallel mechanism [1-3], two kinetostatic outcomes were achieved using two 
different flexure hinge. The stress distribution at all critical points, maximum reach, natural frequencies and the corresponding modal shape were analyzed and confirmed by experiment. The dynamic performance of the 3-DOF flexure mechanism was analyzed by FEA and verified by experiments. Dao and Huang [49], optimized displacement amplification ratio by using Taguchi method-grey relational analysis based fuzzy logic approach. Xu and Li [10] presented many optimum approach to design compliant mechanism using flexible hinge for many applications. The displacement outcome is greater than $1 \mathrm{~mm}$ due to designed amplifier with optimal combination variables using particle swarm optimization. The power function shaped FHs was designed for many applications as presented in reference [11]. The power-function shape flexure hinge obtains higher motion precision than the circular and $\mathrm{V}$-shaped flexure hinge. The general two-segment, circular-axis, symmetric flexure hinges was proposed by Lobontiu and Cullin [12] the new circular-axis flexure design was compared with the existing straight-axis right circular flexure hinge. The leaf flexible hinge was created by Qi et al. [13] the magnification ratio of the mechanism was analyzed and compared with existing methods and verified by the previous test. The Triple-LET and LET FH was faricated by Qiu et al [14], Triple-LET flexure hinge can obtain $180^{\circ}$ without plastic deformation. Three traditional flexible hinges, filleted $\mathrm{V}$-shaped flexure hinges and cycloidal hinge were designed by Tian et al. [15] the closed form compliance equations for filleted $V$-shaped flexure hinges was established and confirmed by FEA. The fillet leaf and circular flexible hinge were presented by Yang et al. [16], the static responses of the planar symmetric superplastic flexible hinge with different notches were analyzed and compared. The circular and leaf flexible hinges were applied to analyze static and dynamic for complex compliant mechanisms by Ling et al. [17], the static displacement and fundamental frequency were compared another existing theoretical method and FEA. Choi et al [18] designed and fabricated the test magnification mechanism model using flexure hinge.

To bypass this limitation and realize the low range of work with a precision position of several nanometers, a magnification mechanism using flexible hinges and driven by a piezoactuator can be utilized. The magnification mechanism has designed for many application has compact size, high magnification ratio, high frequency and light weight. Therefore, the leaf flexible hinge was selected for this mechanism. In this research, the magnification ratio of magnification mechanism was optimized by Taguchi method based on FEA in ANSYS.

\section{Design of mechanism model, set up finite element model and boundary condition}

\subsection{Design of mechanism model}

The model of the magnification mechanism as illustrated in Figure 1 was proposed in this study. The dimensions $\mathrm{A}, \mathrm{B}$ and $\mathrm{C}$ are design variables, respectively as presented in Figure 1. The flexure hinge thickness is constant $0.3 \mathrm{~mm}$ and the other dimensions are constant. 
138

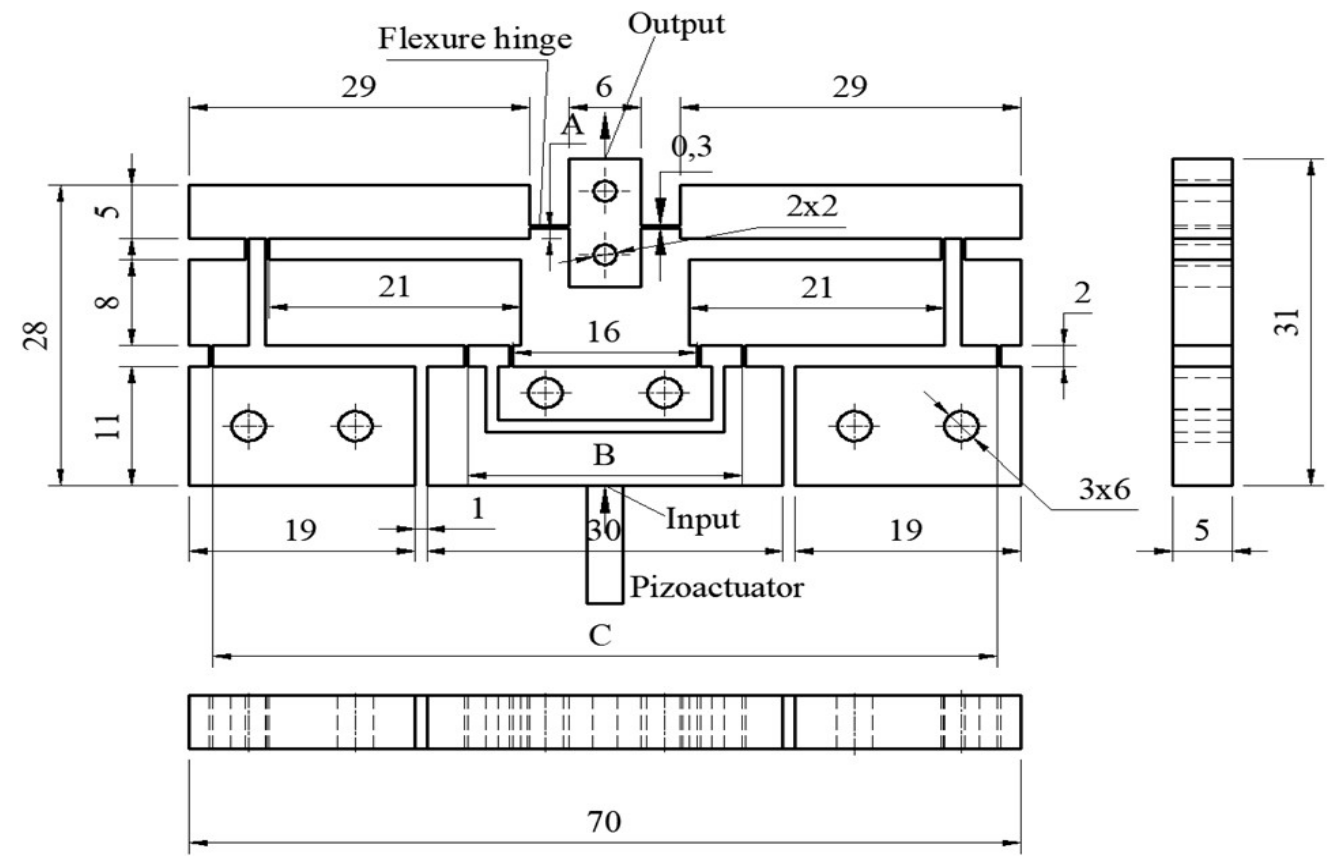

Figure 1. Magnification mechanisms employing flexible hinge

\subsection{Set up finite element model and boundary condition}

The magnification mechanism was designed in Solidworks and then it was insert in to Static Structural and Modal in ANSYS to analyze displacement, principal stress and modal shape frequency. The material AL7075 is used for this mechanism as listed in Table 1. The model was divided meshing by automatically as shown in Figure 2. with 68233 elements and 316289 nodes, element size is equal to $0.5 \mathrm{~mm}$. The boundary condition was set up at six holes' surface horizontal is fix support, and at the B surface is input displacement of $0.01 \mathrm{~mm}$ as illustrated in Figure 2.

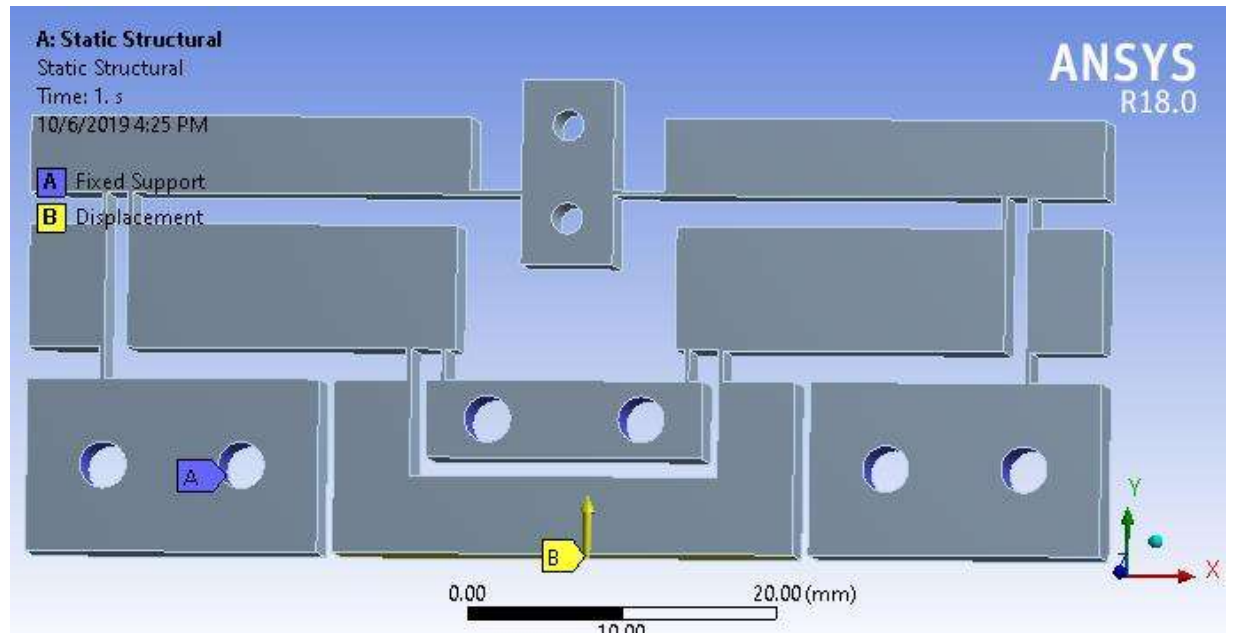

Figure 2. Boundary condition 
Table 1 Mechanical properties of material

\begin{tabular}{cccc}
\hline Material & $\begin{array}{c}\text { Young's modulus } \\
(\mathrm{GPa})\end{array}$ & $\begin{array}{c}\text { Poisson's } \\
\text { ratio }\end{array}$ & $\begin{array}{c}\text { Yield } \\
(\mathrm{MPa})\end{array}$ \\
\hline AL-7075 & 72 & 0.33 & 503 \\
\hline
\end{tabular}

\section{Taguchi Method}

The Taguchi method (TM) in Minitab 18 software is applied to create orthogonal array, the optimal output characteristics obtain as the theory model must point out first, and then the optimal methods were applied. However, the deviations compare with theory model are very large, then the optimal methods cannot be approving. Therefore, this investigation applied Taguchi method based on grey relational analysis and artificial neural network to optimize these output characteristics.

Choose optimization combination parameters for the output characteristics.

Design control factors and their levels.

Lay out $\mathrm{L}_{27}$ orthogonal array

Carried out simulation and collected simulation data.

"Larger is the better" approach: [4, 7, 19-21]

$$
S / N=-10 \log \left(\frac{1}{n} \sum_{i=1}^{n} \frac{1}{y_{i}^{2}}\right)
$$

where $y_{i}$ is the observed data average at the ith experiment, $\mathrm{n}$ is the quality of experiments, In this investigation, $\mathrm{S} / \mathrm{N}$ analysis, analysis of variance and regression equation.

\section{Results and discussion}

\subsection{Set up variables and their level for simulation}

In this investigation, three length dimension were selected as three design variables with changed dimensions and were presented in Table 2, namely variable A changes $0 \mathrm{~mm}$ and $1 \mathrm{~mm}$, variable B changes $20 \mathrm{~mm}, 23 \mathrm{~mm}$ and $26 \mathrm{~mm}$, and variable C changes $60 \mathrm{~mm}, 63 \mathrm{~mm}, 66 \mathrm{~mm}$.

Table 2. Parameters and their levels

\begin{tabular}{lllccc}
\hline & \multirow{2}{*}{ Factor } & & \multirow{2}{*}{ Unit } & \multicolumn{3}{c}{ Levels } \\
\cline { 4 - 6 } & & & 1 & 2 & 3 \\
\hline Length & $\mathrm{A}$ & $\mathrm{mm}$ & 0 & 1.0 & \\
Length & $\mathrm{B}$ & $\mathrm{mm}$ & 20 & 23 & 26 \\
Length & $\mathrm{C}$ & $\mathrm{mm}$ & 60 & 63 & 66 \\
\hline
\end{tabular}

\subsection{Effect analysis of variable $A$}

The output displacement of the mechanism is significantly changed by variable A as depicted in Figure 5 . Because the deformation decreases from $0.3639 \mathrm{~mm}$ to $0.2306 \mathrm{~mm}$ therein variable A increases from $0 \mathrm{~mm}$ to $1 \mathrm{~mm}$, variable $\mathrm{B}$ and $\mathrm{C}$ are equal to $20 \mathrm{~mm}$ and $60 \mathrm{~mm}$, respectively. While the maximum principal stress and modal shape frequency rise from $98.577 \mathrm{MPa}$ to $106.45 \mathrm{MPa}$ and $264.26 \mathrm{~Hz}$ to $340.82 \mathrm{~Hz}$, respectively as illustrated in Figure 6 and Figure 7. The obtained displacement amplification ratio is higher than the previous publication [18]. 


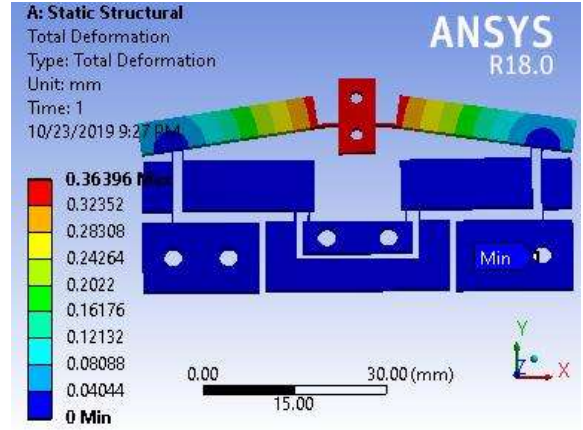

(a) $\mathrm{A}=0 \mathrm{~mm}$

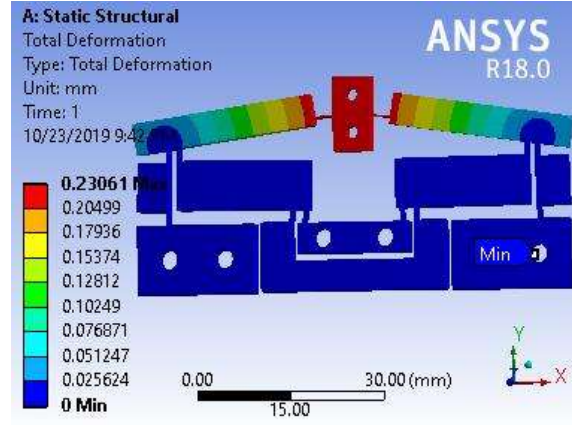

(b) $\mathrm{A}=1 \mathrm{~mm}$

Figure 3. Effect of variable A on deformation

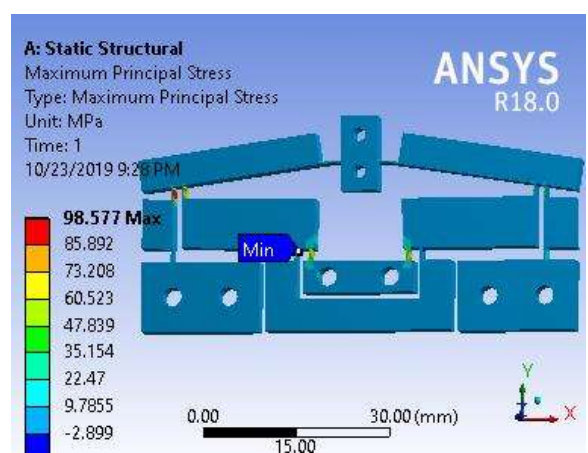

(a) $\mathrm{A}=0 \mathrm{~mm}$

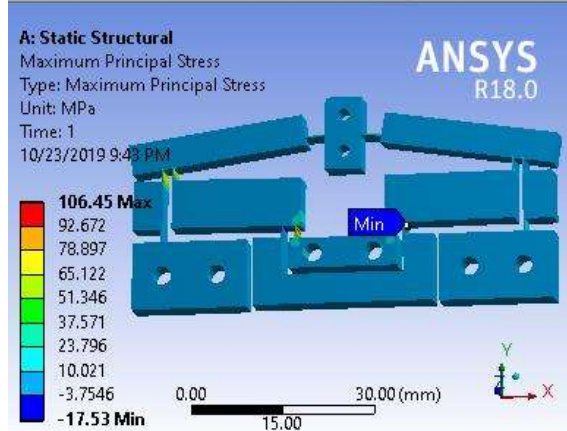

(b) $\mathrm{A}=1 \mathrm{~mm}$

Figure 4. Effect of Variable A on maximum principal stress

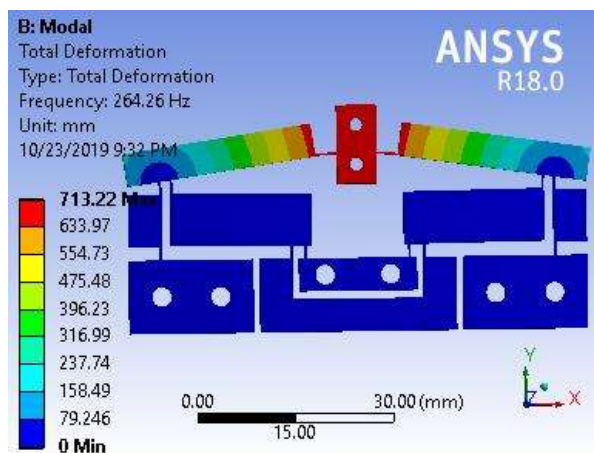

(a) $\mathrm{A}=0 \mathrm{~mm}$

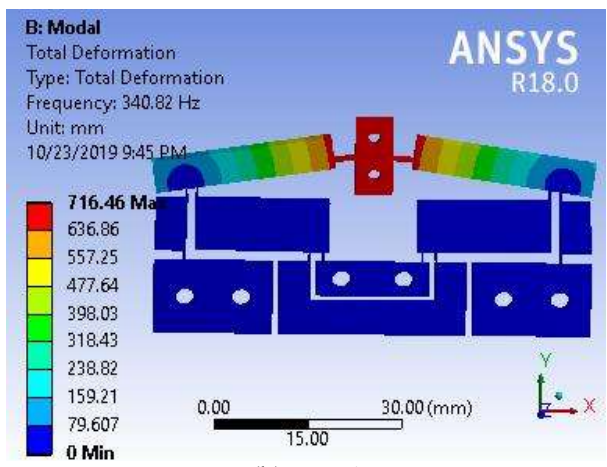

(b) $\mathrm{A}=1 \mathrm{~mm}$

Figure 5. Effect of Variable A on modal shape of frequency

\subsection{Effect analysis of variable $B$}

The output displacement of the mechanism is significantly changed by variable B as depicted in Figure 8 . Because the deformation increases from $0.3383 \mathrm{~mm}$ to $0.42829 \mathrm{~mm}$ therein variable B increases from 20 $\mathrm{mm}$ to $26 \mathrm{~mm}$, variable $A$ and $C$ are equal to $0 \mathrm{~mm}$ and $63 \mathrm{~mm}$, respectively. While the maximum principal stress rises from 103.83 MPa to $132.79 \mathrm{MPa}$ and then reduces to $124.94 \mathrm{MPa}$, this phenomenon is due to variable B increased to $23 \mathrm{~mm}$, the stress have high value and then decreased when variable B was $26 \mathrm{~mm}$, modal shape frequency rises from $262.73 \mathrm{~Hz}$ to $377.44 \mathrm{~Hz}$, respectively as shown in Figure 9 and Figure 10. The obtained displacement amplification ratio is higher than the previous publication [18]. 


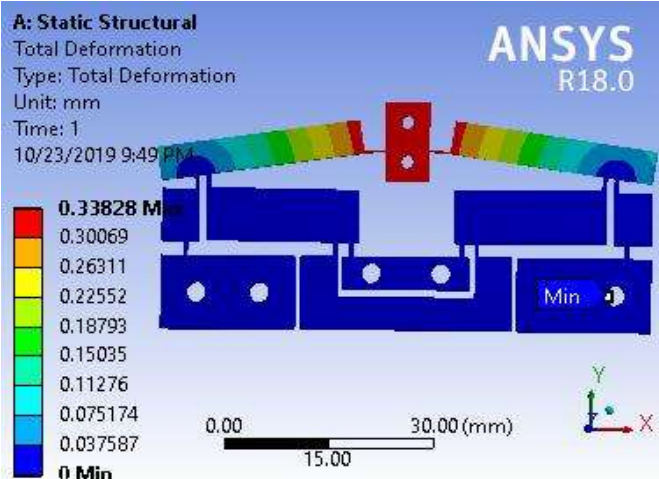

(a) $\mathrm{B}=20 \mathrm{~mm}$

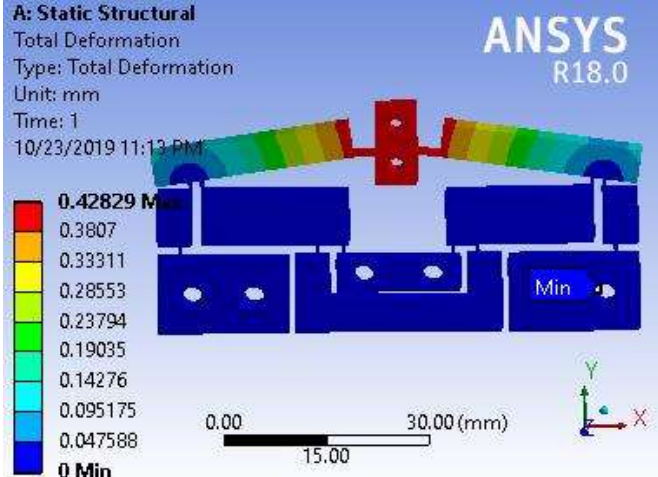

(b) $\mathrm{B}=23 \mathrm{~mm}$

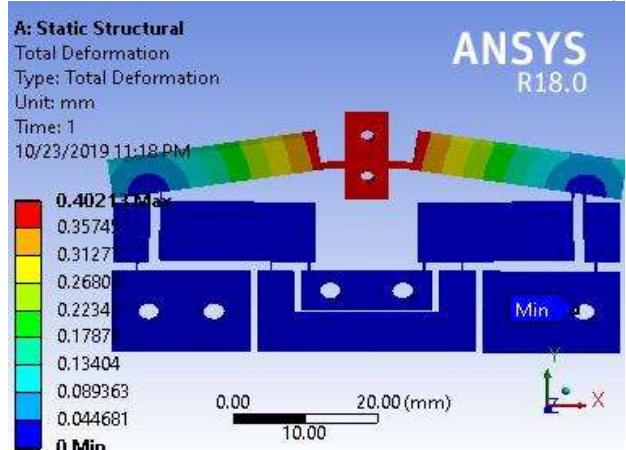

(a) $\mathrm{B}=26 \mathrm{~mm}$

Figure 6. Effect of variable B to deformation

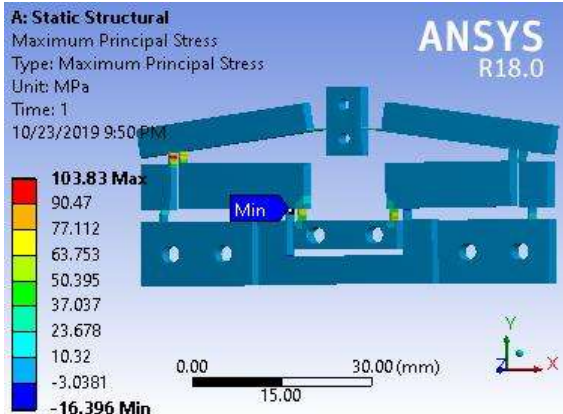

(a) $\mathrm{B}=20 \mathrm{~mm}$

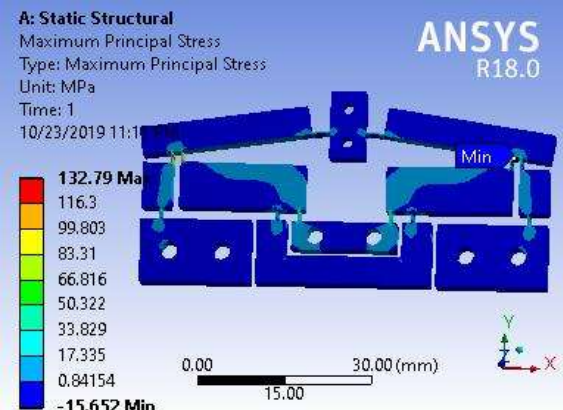

(b) $\mathrm{B}=23 \mathrm{~mm}$

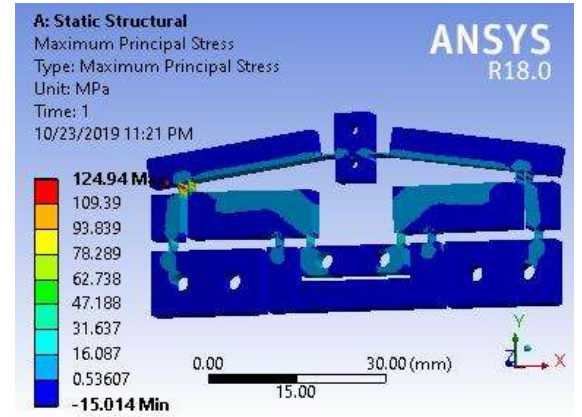

(c) $\mathrm{B}=26 \mathrm{~mm}$

Figure 7. Effect of Variable B to maximum principal stress 


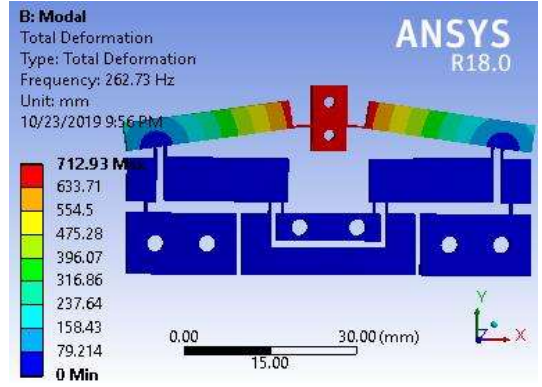

(a) $\mathrm{B}=20 \mathrm{~mm}$

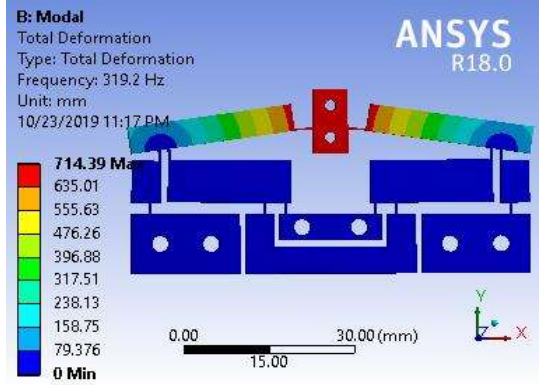

(b) $\mathrm{B}=23 \mathrm{~mm}$

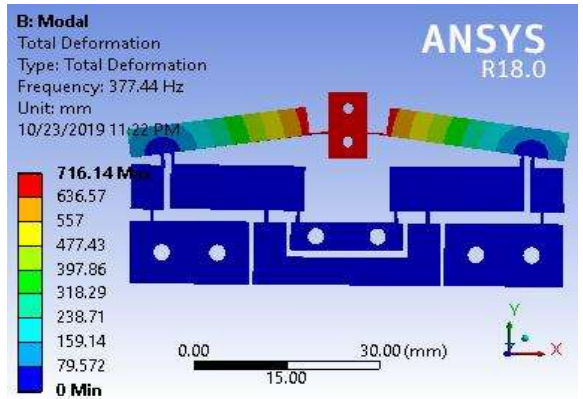

(c) $\mathrm{B}=26 \mathrm{~mm}$

Figure 8. Effect of Variable B to modal shape of frequency

\subsection{Effect analysis of variable $C$}

The output displacement of the mechanism is significantly changed by variable B as depicted in Figure 11. Because the deformation changed from $0.31219 \mathrm{~mm}$ to $0.21979 \mathrm{~mm}$ therein variable $C$ changes from 60 $\mathrm{mm}$ to $66 \mathrm{~mm}$, variable $A$ and $B$ are equal to $1 \mathrm{~mm}$ and $23 \mathrm{~mm}$, respectively. While the maximum principal stress and modal shape frequency changed from $129.65 \mathrm{MPa}$ to $119.59 \mathrm{MPa}$ and $393.98 \mathrm{~Hz}$ to $386.4 \mathrm{~Hz}$, respectively as shown in Figure 12 and Figure 13. The obtained displacement amplification ratio is higher than the previous publication [18].

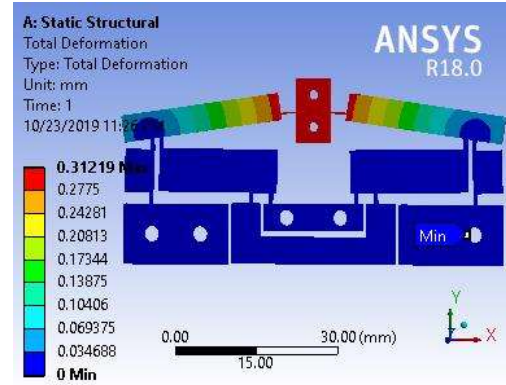

(a) $\mathrm{C}=60 \mathrm{~mm}$

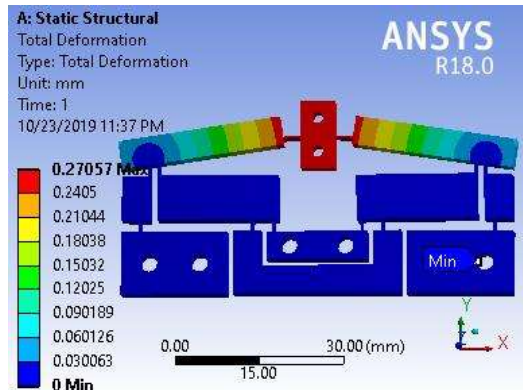

(b) $\mathrm{C}=63 \mathrm{~mm}$

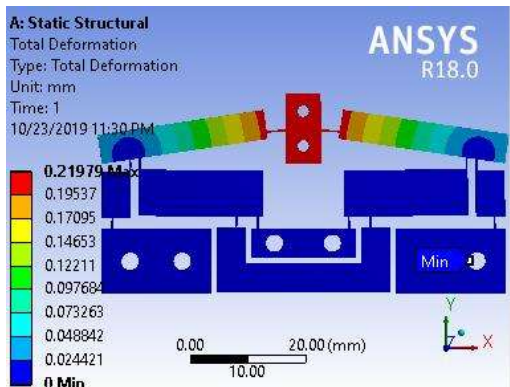

(c) $\mathrm{C}=66 \mathrm{~mm}$

Figure 9. Effect of variable $\mathrm{C}$ to deformation 


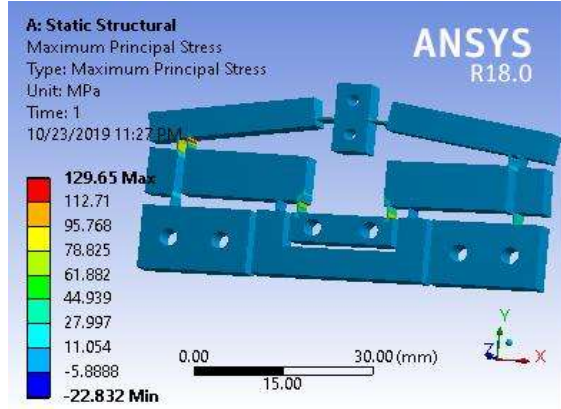

(a) $\mathrm{C}=60 \mathrm{~mm}$

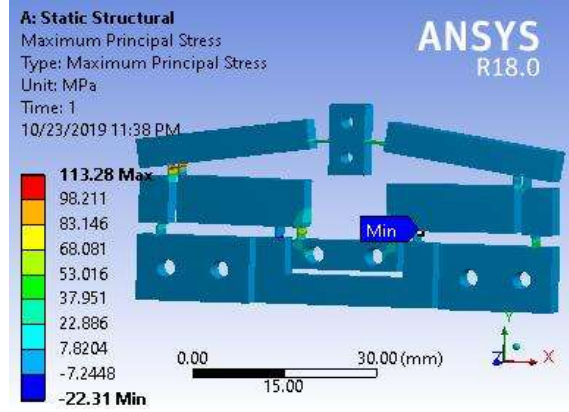

(b) $\mathrm{C}=63 \mathrm{~mm}$

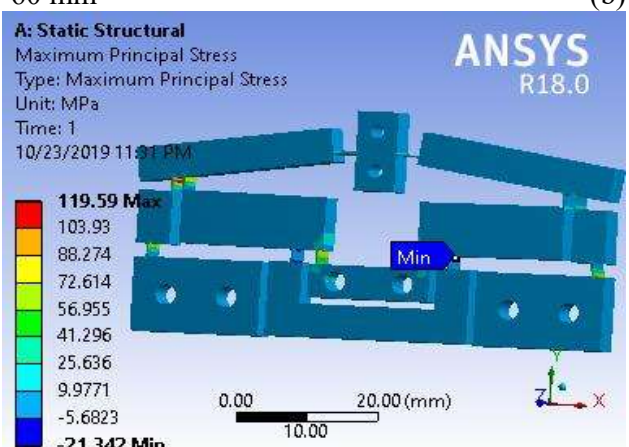

(c) $\mathrm{C}=66 \mathrm{~mm}$

Figure 10. Effect of Variable $\mathrm{C}$ to maximum principal stress

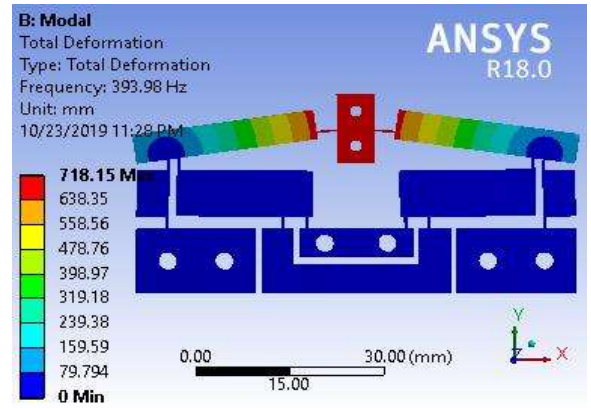

(a) $\mathrm{C}=60 \mathrm{~mm}$

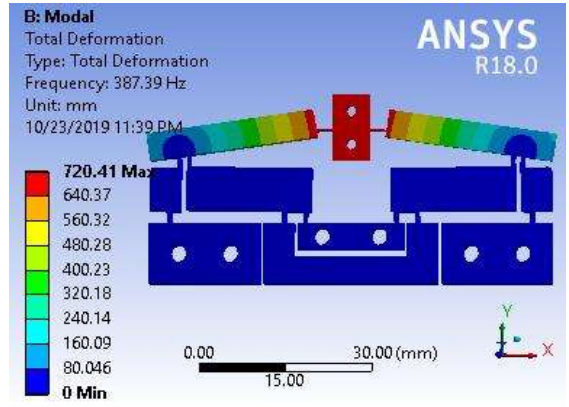

(b) $\mathrm{C}=63 \mathrm{~mm}$

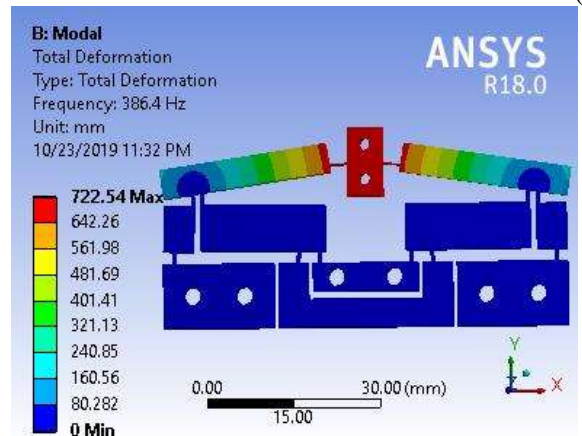

(c) $\mathrm{C}=66 \mathrm{~mm}$

Figure 11. Effect of Variable $\mathrm{C}$ to modal shape of frequency

The orthogonal arrays and FEM outcomes obtained from Minitab 18.0 and ANSYS as listed in Table 3. The displacement outcomes were utilized to select one combination parameters which have high magnification ratio of displacement by Taguchi method, through signal to noise analysis. 
144

ANALYSIS AND OPTIMAL DESIGN THE EFFECT OF DESIGN VARIABLES

ONMAGANIFICATION RATIO OF A MAGANIFICATION MACHANISM EMPLOYING FLEXIBLE HINGE

Table 3. Orthogonal arrays, FEM results

\begin{tabular}{ccccc}
\hline Trial No. & A & B & C & Displacement $(\mathrm{mm})$ \\
\hline 1 & 0 & 20 & 60 & 0.3640 \\
2 & 0 & 20 & 63 & 0.3383 \\
3 & 0 & 20 & 66 & 0.3105 \\
4 & 0 & 23 & 60 & 0.4392 \\
5 & 0 & 23 & 63 & 0.4283 \\
6 & 0 & 23 & 66 & 0.4032 \\
7 & 0 & 26 & 60 & 0.4201 \\
8 & 0 & 26 & 63 & 0.4213 \\
9 & 0 & 26 & 66 & 0.3858 \\
10 & 1 & 20 & 60 & 0.2306 \\
11 & 1 & 20 & 63 & 0.1883 \\
12 & 1 & 20 & 66 & 0.1514 \\
13 & 1 & 23 & 60 & 0.3130 \\
14 & 1 & 23 & 63 & 0.2706 \\
15 & 1 & 23 & 66 & 0.2200 \\
16 & 1 & 26 & 60 & 0.3130 \\
17 & 1 & 26 & 63 & 0.2875 \\
18 & 1 & 26 & 66 & 0.2386 \\
\hline
\end{tabular}

\subsection{Analysis of signal to noise ratio}

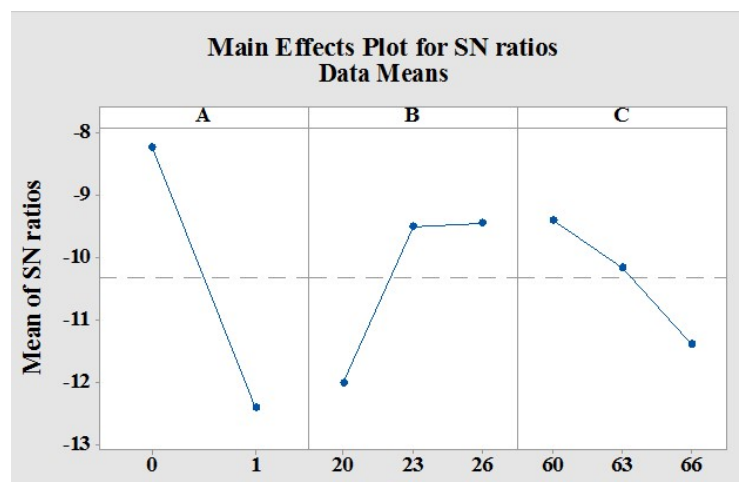

a)

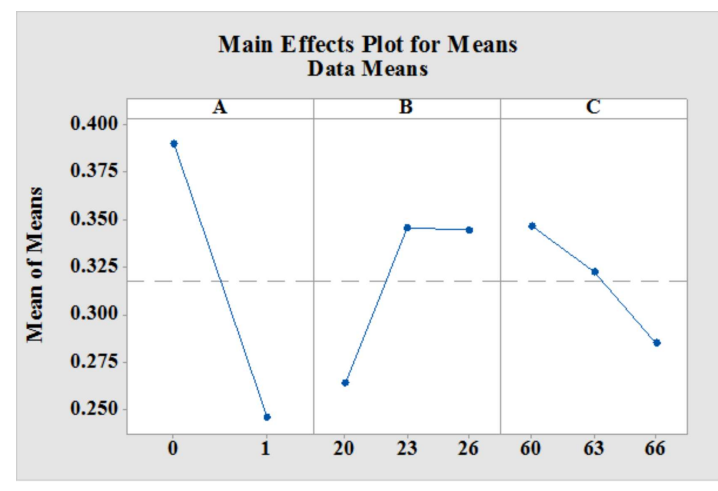

b)

Figure 12. a) $\mathrm{S} / \mathrm{N}$ ratio plot, b) Mean plot

The signal to noise analysis outcomes as presented in Figure 12a, it obtained combination parameters at optimal level is $\mathrm{A} 1 \mathrm{~B} 2 \mathrm{C} 1$ and the same result as illustrated in Figure $12 \mathrm{~b}$ is mean analysis results. The mean values and signal to noise values was pointed out in Table 4. In this Table, maximum values are optimal values. Maximum values of means were utilized to predict displacement or displacement amplification ratio of the magnification mechanism.

Table 4. Response Table for signal to noise ratios and means

\begin{tabular}{ccccccccc}
\hline \multicolumn{3}{c|}{ For signal to noise ratios } & \multicolumn{4}{c}{ For means } \\
\hline Level & A & B & C & Level & A & B & C \\
\hline 1 & -8.230 & -11.999 & -9.396 & 1 & 0.3901 & 0.2638 & 0.3466 \\
2 & -12.400 & -9.499 & -10.162 & 2 & 0.2459 & 0.3457 & 0.3224 \\
3 & & -9.446 & -11.386 & 3 & & 0.3444 & 0.2849 \\
Delta & 4.170 & 2.553 & 1.990 & Delta & 0.1442 & 0.0819 & 0.0617 \\
Rank & 1 & 2 & 3 & Rank & 1 & 2 & 3 \\
\hline
\end{tabular}




\subsection{Analysis of variance}

The analysis of variance outcomes as listed in Table 5, in this Table indicated degree of freedom of variable $\mathrm{A}$ is 1 , variable $\mathrm{B}$ is 2 , variable $\mathrm{C}$ is 2 . The contribution percent of variable $\mathrm{A}$ is $69.95 \%$, variable $\mathrm{B}$ is $19.72 \%$, variable $\mathrm{C}$ is $8.68 \%$ and error is $1.64 \%$. The $\mathrm{F}$-values are greater than 2 and $\mathrm{P}$-values are equal to zero. The problems identified that design variables have significantly influenced on displacement of magnification where variable $\mathrm{A}$ has the most influence, then variable $\mathrm{B}$ and finally variable $\mathrm{C}$. the $\mathrm{R}$-square is equal to $98.36 \%$, R-square(adj) is $97.67 \%$, R-square(Pred) is $96.3 \%$.

Table 5. Analysis of Variance

\begin{tabular}{cccccccc}
\hline Source & DF & Seq SS & Contribution & Adj SS & Adj MS & F-Value & P-Value \\
\hline A & 1 & 0.093557 & $69.95 \%$ & 0.093557 & 0.093557 & 510.42 & 0.000 \\
B & 2 & 0.026379 & $19.72 \%$ & 0.026379 & 0.013190 & 71.96 & 0.000 \\
C & 2 & 0.011607 & $8.68 \%$ & 0.011607 & 0.005804 & 31.66 & 0.000 \\
Error & 12 & 0.002200 & $1.64 \%$ & 0.002200 & 0.000183 & & \\
Total & 17 & 0.133743 & $100.00 \%$ & & & & \\
\hline
\end{tabular}

R square $=98.36 \%, R$ square $(\operatorname{adj})=97.67 \%, R$ square $($ Pred $)=96.30 \%$

\subsection{Analysis of regression}

Regression Equation as depicted in Eq. (2) and drawn out in Figure 13, indicated that the change of displacement in 18 simulations. The regression values and simulation values are good agree with each other. Because the graphs of their lie near each other.

$$
\text { Displacement }=-1.688-0.14419 \mathrm{x}+0.2260 \mathrm{y}-0.01029 \mathrm{z}-0.004622 \mathrm{y} * \mathrm{y}
$$

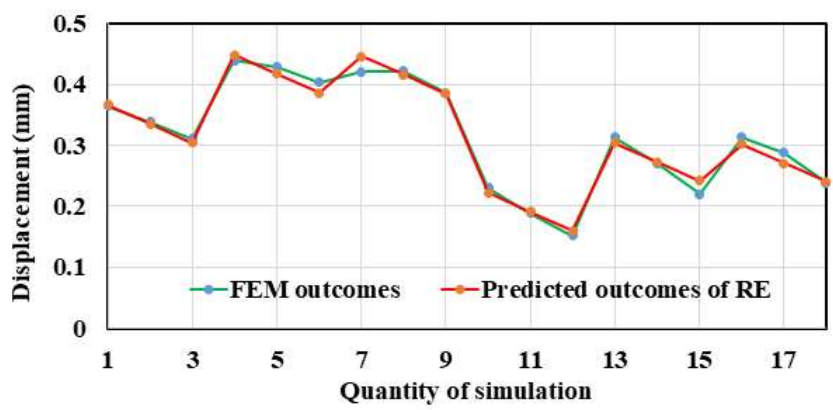

Figure 13. Compare FEM results with predicted results of RE

\subsection{Predicted and conformation}

$$
\begin{aligned}
& \mu_{D}=D_{D}+\sum_{i=1}^{q}\left(D_{0}-D_{D}\right)=x 1+y 3+z 1-2 D_{D} \\
& \mu_{G}=0.3901+0.3444+0.3466-2 \times 0.3180=0.4451(\mathrm{~mm}) \\
& C I_{C E}= \pm \sqrt{F_{\alpha}(1, f e) \operatorname{Ve}\left(\frac{1}{n_{e f f}}+\frac{1}{R_{e}}\right)}
\end{aligned}
$$

At confidence interval 95\%, error interval is determined as following:

$$
\text { At } \alpha=0.05, \mathrm{fe}=16, \mathrm{~F}_{0.05}(1,12)=4.7472 \text { [22], } \mathrm{Ve}=0.000183, \mathrm{R}=5, \mathrm{Re}=1, \mathrm{n}=18 \text {. }
$$


146 ANALYSIS AND OPTIMAL DESIGN THE EFFECT OF DESIGN VARIABLES

ONMAGANIFICATION RATIO OF A MAGANIFICATION MACHANISM EMPLOYING FLEXIBLE HINGE

$$
C I_{C E}= \pm \sqrt{4.7472 \times 0.000183 \times\left(\frac{1}{\frac{18}{1+5}}+1\right)}= \pm 0.034,0.4110<\mu_{\text {confirmation }}<0.4791
$$

The forecasted value of displacement was obtained $0.4451 \mathrm{~mm}$ by Eq. (3) and error confirm is equal to in \pm 0.034 interval.

\section{Conclusions}

The influences of three variables A and B on displacement, maximum principal stress and the first modal shape frequency were analyzed by FEA. The outcomes identified that the variables A, B and C have significantly influenced on magnification ratio of the magnification mechanism. where variable $\mathrm{A}$ has the most influence, then variable $B$ and finally variable $C$. The variables made to displacement changes from $0.3383 \mathrm{~mm}$ to $0.4283 \mathrm{~mm}$ corresponding with the magnification ratio changes from 33.83 times to 42.83 times. While the maximum principal stress increases from 103.83 MPa to132.79 $\mathrm{MPa}$ and then reduces to 124.94 MPa. The variable A made to reduce magnification ratio from 36.39 times to 23.06 times. While the maximum principal stress increases from $98.57 \mathrm{MPa}$ to106.45 MPa. The analysis of variance and signal to noise analysis also confirmed that Variables A, B and C have significantly affected on displacement or magnification ratio at the same the simulation results. The optimal outcome of displacement achieved $0.4392 \mathrm{~mm}$, while predicted result of displacement is $0.4451 \mathrm{~mm}$, the results are good agree with error is $1.33 \%$.

\section{References}

[1] Y. K. Yong and T.-F. Lu, "Kinetostatic modeling of 3-RRR compliant micro-motion stages with flexure hinges," Mechanism and Machine Theory, vol. 44, pp. 1156-1175, 2009.

[2] U. Bhagat, B. Shirinzadeh, L. Clark, P. Chea, Y. Qin, Y. Tian, et al., "Design and analysis of a novel flexurebased 3-DOF mechanism," Mechanism and Machine Theory, vol. 74, pp. 173-187, 2014.

[3] Y. Tian, B. Shirinzadeh, and D. Zhang, "Design and dynamics of a 3-DOF flexure-based parallel mechanism for micro/nano manipulation," Microelectronic Engineering, vol. 87, pp. 230-241, 2010.

[4] T.-P. Dao, "Multiresponse Optimization of a Compliant Guiding Mechanism Using Hybrid Taguchi-Grey Based Fuzzy Logic Approach," Mathematical Problems in Engineering, vol. 2016, pp. 1-17, 2016.

[5] T.-P. Dao and S.-C. Huang, "Robust design for a flexible bearing with 1-DOF translation using the Taguchi method and the utility concept," Journal of Mechanical Science and Technology, vol. 29, pp. 3309-3320, 2015.

[6] T.-P. Dao and S.-C. Huang, "Design and analysis of a compliant micro-positioning platform with embedded strain gauges and viscoelastic damper," Microsystem Technologies, vol. 23, pp. 441-456, 2016.

[7] T.-P. Dao and S.-C. Huang, "Optimization of a two degrees of freedom compliant mechanism using Taguchi method-based grey relational analysis," Microsystem Technologies, vol. 23, pp. 4815-4830, 2017.

[8] T.-P. Dao and S.-C. Huang, "Design and multi-objective optimization for a broad self-amplified 2-DOF monolithic mechanism," Sādhanā, vol. 42, pp. 1527-1542, 2017.

[9] T.-P. Dao and S.-C. Huang, "Compliant thin-walled joint based on zygoptera nonlinear geometry," Journal of Mechanical Science and Technology, vol. 31, pp. 1293-1303, 2017.

[10] Q. Xu and Y. Li, "Analytical modeling, optimization and testing of a compound bridge-type compliant displacement amplifier," Mechanism and Machine Theory, vol. 46, pp. 183-200, 2011.

[11] Q. Li, C. Pan, and X. Xu, "Closed-form compliance equations for power-function-shaped flexure hinge based on unit-load method," Precision Engineering, vol. 37, pp. 135-145, 2013.

[12] N. Lobontiu and M. Cullin, "In-plane elastic response of two-segment circular-axis symmetric notch flexure hinges: The right circular design," Precision Engineering, vol. 37, pp. 542-555, 2013.

[13] K.-q. Qi, Y. Xiang, C. Fang, Y. Zhang, and C.-s. Yu, "Analysis of the displacement amplification ratio of bridge-type mechanism," Mechanism and Machine Theory, vol. 87, pp. 45-56, 2015.

[14] L. Qiu, S. Yin, and Z. Xie, "Failure analysis and performance comparison of Triple-LET and LET flexure hinges," Engineering Failure Analysis, vol. 66, pp. 35-43, 2016.

[15] Y. Tian, B. Shirinzadeh, and D. Zhang, "Closed-form compliance equations of filleted V-shaped flexure hinges for compliant mechanism design," Precision Engineering, vol. 34, pp. 408-418, 2010. 
[16] M. Yang, Z. Du, and W. Dong, "Modeling and analysis of planar symmetric superelastic flexure hinges," Precision Engineering, vol. 46, pp. 177-183, 2016.

[17] M. Ling, J. Cao, Z. Jiang, and J. Lin, "A semi-analytical modeling method for the static and dynamic analysis of complex compliant mechanism," Precision Engineering, 2017.

[18] S. B. Choi, S. S. Han, Y. M. Han, and B. S. Thompson, "A magnification device for precision mechanisms featuring piezoactuators and flexure hinges: Design and experimental validation," Mechanism and Machine Theory, vol. 42, pp. 1184-1198, 2007.

[19] T. P. Dao and S. C. Huang, "Optimization of Multiresponse Performance Measure in Slider-Rocker Compliant Mechanism Using Fuzzy-Taguchi Method," Advanced Materials Research, vol. 683, pp. 708-711, 2013.

[20] S.-C. Huang and T.-P. Dao, "Multi-objective Optimal Design of a 2-DOF Flexure-Based Mechanism Using Hybrid Approach of Grey-Taguchi Coupled Response Surface Methodology and Entropy Measurement," Arabian Journal for Science and Engineering, vol. 41, pp. 5215-5231, 2016.

[21] T. Kivak, "Optimization of surface roughness and flank wear using the Taguchi method in milling of Hadfield steel with PVD and CVD coated inserts," Measurement, vol. 50, pp. 19-28, 2014.

[22] R. K. Roy, " A primer on the Taguchi method " Society of Manufacturing Engineers, 2010.

Ngày gửi bài: 25/12/2019

Ngày chấp nhận đăng: 13/04/2020 